\title{
In situ earthworm breeding in orchards significantly improves the growth, quality and yield of papaya (Carica papaya L.)
}

\author{
Huimin Xiang ${ }^{1,2}$, Jia-en Zhang ${ }^{\text {Corresp., }}{ }^{1,2}$, Lei Guo ${ }^{1,2}$, Benliang Zhao ${ }^{1,2}$ \\ ${ }^{1}$ College of Natural Resources and Environment, South China Agricultural University, Guangzhou, China \\ ${ }^{2}$ Key Laboratory of Agro-environment in the Tropics, South China Agricultural University, Guangzhou, China \\ Corresponding Author: Jia-en Zhang \\ Email address: jeanzh@scau.edu.cn
}

The aim of this study was to compare the effects of four fertilizer applications-control (C), chemical fertilizer $(F)$, compost $(O)$, and in situ earthworm breeding $(E)$ - on the growth, quality and yield of papaya (Carica papaya L.) . In this study, $5 \mathrm{~g}_{\text {plant }}^{-1}$ urea $\left(\mathrm{CH}_{4} \mathrm{~N}_{2} \mathrm{O}, \% \mathrm{~N}\right.$ $=46.3 \%)$ and $100 \mathrm{~g} \mathrm{plant}^{-1}$ microelement fertilizer was applied to each treatment. Then the fertilizer applications of these four treatments are different from each other. The results showed that the $E$ treatment had the highest growth parameters over the whole growth period. At 127 days after transplantation, the plant heights were ordered $E>F>0$ $>\mathrm{C}$, and the stem diameters were $\mathrm{E}>\mathrm{F}>\mathrm{O}>\mathrm{C}$, with significant differences between all treatments. Soluble-solid, sugar, vitamin $\mathrm{C}$, and protein content significantly increased in the $E$ treatment. In addition, the total acid and the electrical conductivity of the fruit significantly decreased in the $E$ treatment. Fruit firmness clearly increased in the 0 treatment, and it decreased in the $F$ treatment. The fresh individual fruit weights, fruit numbers, and total yields were greatly improved in the $\mathrm{F}$ and $\mathrm{E}$ treatments, and the total yield of the $E$ treatment was higher than that in the $F$ treatment. In conclusion, the in situ earthworm breeding treatment performed better than conventional compost and chemical fertilizer treatments. Furthermore, in situ earthworm breeding may be a potential organic fertilizer application in orchards because it not only improves the fruit quality and yield but also reduces the amount of organic wastes from agriculture as a result of the activities of earthworms. 


\section{In situ earthworm breeding in orchards significantly improves the}

\section{2 growth, quality and yield of papaya (Carica papaya L.)}

3 Huimin Xiang, ${ }^{\mathrm{a}, \mathrm{b}}$ Jia-en Zhang ${ }^{\mathrm{a}, \mathrm{b},{ }^{*}}$, Lei Guo ${ }^{\mathrm{a}, \mathrm{b}}$, Benliang Zhao ${ }^{\mathrm{a}, \mathrm{b}}$

4 a College of Natural Resources and Environment, South China Agricultural University, 5 Guangzhou 510642, China

6 bey Laboratory of Agro-environment in the Tropics, Ministry of Agriculture, South China 7 Agricultural University, Guangzhou 510642, China

Correspondence should be addressed to Jia-en Zhang; jeanzh@scau.edu.cn

\section{Abstract}

The aim of this study was to compare the effects of four fertilizer applications - control (C), chemical fertilizer $(\mathrm{F})$, compost $(\mathrm{O})$, and in situ earthworm breeding $(\mathrm{E})$ — on the growth, quality and yield of papaya (Carica papaya L.). In this study, $5 \mathrm{~g}$ plant $^{-1}$ urea $\left(\mathrm{CH}_{4} \mathrm{~N}_{2} \mathrm{O}, \% \mathrm{~N}=46.3 \%\right.$ ) and $100 \mathrm{~g}$ plant $^{-1}$ microelement fertilizer was applied to each treatment. Then the fertilizer applications of these four treatments are different from each other. The results showed that the E treatment had the highest growth parameters over the whole growth period. At 127 days after transplantation, the plant heights were ordered $\mathrm{E}>\mathrm{F}>\mathrm{O}>\mathrm{C}$, and the stem diameters were $\mathrm{E}>\mathrm{F}>\mathrm{O}>\mathrm{C}$, with significant differences between all treatments. Soluble-solid, sugar, vitamin $\mathrm{C}$, and protein content significantly increased in the $\mathrm{E}$ treatment. In addition, the total acid and the electrical conductivity of the fruit significantly decreased in the E treatment. Fruit firmness clearly increased in the $\mathrm{O}$ treatment, and it decreased in the $\mathrm{F}$ treatment. The fresh individual fruit weights, fruit numbers, and total yields were greatly improved in the $\mathrm{F}$ and $\mathrm{E}$ treatments, and the total yield of the $\mathrm{E}$ treatment was higher than that in the F treatment. In conclusion, the in situ earthworm breeding treatment performed better than conventional compost and chemical fertilizer treatments. Furthermore, in situ earthworm breeding may be a potential organic fertilizer application in orchards because it not only improves the fruit quality and yield but also reduces the amount of organic wastes from agriculture as a result of the activities of earthworms.

Keywords: Earthworm in situ breeding; Papaya; Plant growth; Fruit quality; Total yield 


\section{Introduction}

31 Papaya (Carica papaya L.) is one of the most important fruit crops which is widely cultivated in tropical and subtropical areas. It is rich in nutrition, sugar, vitamin $\mathrm{C}$, protein, and amino acids, and it is the primary raw material that contains papain. Papaya is also widely planted in southern China, especially in Guangdong, Yunnan, and Hainan Provinces. However, papaya production is frequently low and unreliable. Although chemical fertilizer application is a common method for improving papaya yields, it is unfriendly to the environment . It can impair soil structure, and decrease soil fertility by reducing the carbon and nitrogen content (Ngo et al., 2012). Moreover, chemical fertilizer application can also affect animal and human health (Vu et al., 2007), such as some fish in the rice paddy were killed, and also it is bad for human health through the food chain due to the content of heavy metals in chemical fertilizer. For these reasons, the importance of organic fertilization has been increasing in recent years, and suitable organic amendments including composting, vermicomposting and in situ earthworm breeding have become promising biological ways to improve the growth, fruit quality and yield of papayas. fertility and plant nutrition (Cantanazaro et al., 1998; Caravaca et al., 2002), and this method is especially appropriate for sustainable agriculture. While among the soil organisms favored by organic fertilization, earthworms have been identified as a key functional group (Jouquet et al., 2006). Earthworms have a great ability to consume organic wastes, reducing the volume by approximately $50 \%$ and expelling the digested materials as castings, which are useful for soil amendments and may be easily stored for agricultural use (Tomati et al., 1985). In situ earthworm breeding in orchards usually has three important advantages. First, this method can be used to manage a large amount of organic wastes from agriculture. At present, earthworms have 
attracted a great deal of attention as an efficient and low-cost means of composting organic wastes such as animal wastes and crop residues (Ndegwa and Thompson, 2001; Singh et al., 2008). They not only reduce organic waste pollution but also improve the environment of rural areas. Second, this method produces a large amount of high-quality compost, known as "vermicompost," which comes from the biological degradation of organic wastes by earthworms (Chaoui et al., 2003). Third, earthworm activities improve the soil structure, microbial activity and biodiversity, and soil OM dynamics (Jongmans et al., 2001; Pulleman et al., 2005; Jouquet et al., 2007; Bottinelli et al., 2010; Bernard et al., 2011). Furthermore, earthworm activity is also an important factor that controls vegetation dynamics and has a positive influence on plant growth (Doan et al., 2013). However, there is still a lack of knowledge about the effects of in situ earthworm breeding in orchards on the growth, quality, and yield of fruits.

Thus, the aim of our study was to evaluate the effects of chemical fertilizer, compost, and in situ earthworm breeding in orchards on the growth, fruit quality, and yield of papayas and to explore a potential application of organic fertilizer that can not only be used as a substitute for chemical fertilization but also improve papaya yield and quality.

\section{Materials and methods}

\subsection{Site description}

This study was conducted at Yinghuwan reclamation land, Xinhui district, Jiangmen city $\left(23^{\circ} \mathrm{N}, 113^{\circ} \mathrm{E}\right)$, which is located in the southwestern Pearl River Delta in Guangdong Province, China. The area is characterized by a typical subtropical monsoon climate. The average annual precipitation is $1,763 \mathrm{~mm}$, of which approximately $80 \%$ falls during the wet season between May and September. The annual effective 
monthly mean temperatures in January and July, respectively. The annual solar radiation is $110 \mathrm{kcal} \mathrm{cm}^{-2}$. The background values for the soil $\mathrm{pH}$, soil organic matter, total nitrogen $(\mathrm{N})$, total phosphorus $(\mathrm{P})$, total potassium, available $\mathrm{N}$, available $\mathrm{P}$, and available potassium are $6.72,24.26 \mathrm{~g} \mathrm{~kg}^{-1}, 1.21 \mathrm{~g} \mathrm{~kg}^{-1}, 0.72 \mathrm{~g} \mathrm{~kg}^{-1}, 22.29 \mathrm{~g} \mathrm{~kg}^{-1}$, $80.92 \mathrm{mg} \mathrm{kg}^{-1}, 62.80 \mathrm{mg} \mathrm{kg}^{-1}$, and $286.42 \mathrm{mg} \mathrm{kg}^{-1}$, respectively.

\subsection{Experimental design and treatments}

This experiment was conducted in a Hawaiian papaya orchard from March to December of 2008. Hawaiian papaya plants were transplanted on March 31 , with a planting space of $3.1 \mathrm{~m} \times 2.7 \mathrm{~m}$. Four treatments were used in our study. These treatments consisted of a control (C), chemical fertilizer (F), compost (O), and in situ earthworm breeding (E). All treatments were repeated three times during the experiment. $5 \mathrm{~g}^{\text {plant }}{ }^{-1}$ urea $\left(\mathrm{CH}_{4} \mathrm{~N}_{2} \mathrm{O}, \% \mathrm{~N}=46.3 \%\right)$ and $100 \mathrm{~g} \mathrm{plant}^{-1}$ microelement fertilizer was applied to each treatment. Since then, no chemical or fertilizer were applied to $\mathrm{C}$. But $45 \mathrm{~g}$ plant $^{-1}$ urea $\left(\mathrm{CH}_{4} \mathrm{~N}_{2} \mathrm{O}, \% \mathrm{~N}=46.3 \%\right), 100 \mathrm{~g} \mathrm{plant}^{-1}$ phosphate $\left(\% \mathrm{P}_{2} \mathrm{O}_{5}, \mathrm{P}=12 \%\right), 500 \mathrm{~g}^{\text {plant }}{ }^{-1}$ compound fertilizer was applied in the $\mathrm{F}$ treatment. The $\mathrm{O}$ was prepared by using cow manure. $10 \mathrm{~kg}$ plant $^{-1}$ cow manure was applied to the $\mathrm{O}$ treatment. The $\mathrm{E}$ field pattern can be found in Fig. 1. An earthworm bed (length: $16 \mathrm{~m}$, above width: $40 \mathrm{~cm}$, below width: $60 \mathrm{~cm}$, and height: $30 \mathrm{~cm}$ ) was prepared approximately $50 \mathrm{~cm}$ from the papaya plant in each plot. We added $4.858 \mathrm{~kg} \mathrm{~m}^{-3}$ organic wastes which produced in the process of producing beer to the bottom of the bed, and then we put earthworms (Eisenia fetida) into it at a density of $8 \mathrm{~g}$ per $\mathrm{m}^{2}$. Next, we put rice straw and sun shading net on the bed, and water and organic wastes were added regularly so that we could provide a better environment for the earthworms' growth and reproduction. The providing nutrients of $\mathrm{O}$ and $\mathrm{E}$ were listed in Table 1.

On April 28, 5 g plant $^{-1}$ urea $\left(\mathrm{CH}_{4} \mathrm{~N}_{2} \mathrm{O}, \% \mathrm{~N}=46.3 \%\right)$ was added to each plot. On May $24,100 \mathrm{~g} \mathrm{plant}^{-1}$ compound fertilizer $(\% \mathrm{~N}-\% \mathrm{P}-\% \mathrm{~K}=15 \%-15 \%-15 \%)$ was applied to the $\mathrm{F}$ treatment, and $1 \mathrm{~kg} \mathrm{plant}^{-1}$ cow 
102

103

104

105

106

01

manure was applied to the $\mathrm{O}$ treatment. The chemical fertilizer and compost was applied at the base of the papaya plants. On June 12, the application of $\mathrm{F}$ and $\mathrm{O}$ was the same as that on May 24. On July 4, $40 \mathrm{~g} \mathrm{plant}^{-1}$ urea and 100 g plant $^{-1}$ phosphate $\left(\% \mathrm{P}_{2} \mathrm{O}_{5}, \mathrm{P}=12 \%\right)$ were applied to the $\mathrm{F}$ treatment, and $2 \mathrm{~kg} \mathrm{plant}^{-1}$ cow manure was applied to the $\mathrm{O}$ treatment. On August 25, $100 \mathrm{~g}^{\text {plant }}{ }^{-1}$ compound fertilizer was applied to the $\mathrm{F}$, and $3 \mathrm{~kg}$ plant $\mathrm{t}^{-1}$ cow manure was applied to the $\mathrm{O}$. Simultaneously, $100 \mathrm{~g} \mathrm{plant}^{-1}$ microelement fertilizer was applied to each treatment. On September 12, $200 \mathrm{~g}$ plant $^{-1}$ compound fertilizer was distributed over the F, and $3 \mathrm{~kg}$ plant $^{-1}$ cow manure was distributed over the $\mathrm{O}$. The total amounts of $\mathrm{N}, \mathrm{P}, \mathrm{K}$, organic matter and microelements that were included in the fertilizer application for each treatment were analyzed (Table 2).

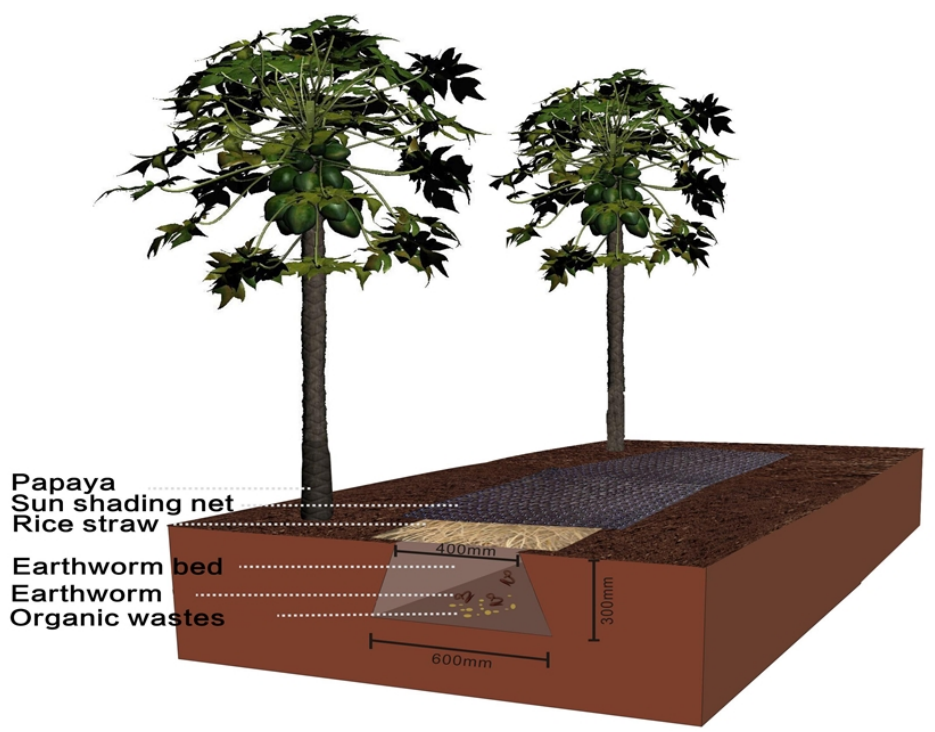

Figure 1: The E field pattern in a papaya orchard. E: in situ earthworm breeding.

Table 1 The providing nutrient of compost and in situ earthworm breeding. O-compost, E-in situ earthworm breeding.

\begin{tabular}{cccccc}
\hline Treatment & $\mathrm{pH}$ & Total N $(\mathrm{g} / \mathrm{kg})$ & Total P $(\mathrm{g} / \mathrm{kg})$ & Total K $(\mathrm{g} / \mathrm{kg})$ & Organic matter $(\mathrm{g} / \mathrm{kg})$ \\
\hline $\mathrm{O}$ & 6.12 & 9.58 & 4.23 & 4.03 & 193.22 \\
$\mathrm{E}$ & 5.98 & 11.64 & 6.64 & 7.60 & 179.70 \\
\hline
\end{tabular}


108 Table 2 The total amounts of N, P, K, organic matter and microelements in the fertilizer application by human for 109 each treatment. C-control, F-chemical fertilizer, O-compost, and E-in situ earthworm breeding.

\begin{tabular}{cccccc}
\hline Treatment & Total N $(\mathrm{g})$ & Total P $(\mathrm{g})$ & Total K $(\mathrm{g})$ & Organic matter $(\mathrm{kg})$ & Microelements $(\mathrm{g})$ \\
\hline $\mathrm{C}$ & 2.32 & 0.00 & 0.00 & 0.00 & 50.00 \\
$\mathrm{~F}$ & 110.88 & 102.00 & 90.00 & 0.00 & 50.00 \\
$\mathrm{O}$ & 98.12 & 42.30 & 40.30 & 1.93 & 50.00 \\
$\mathrm{E}$ & 2.32 & 0.00 & 0.00 & 0.00 & 50.00 \\
\hline
\end{tabular}

110

\subsection{Measurements}

112 Measurements of the plant height $(\mathrm{cm})$ and stem diameter $(\mathrm{cm})$ were recorded for seven plants from each replication at $38,55,76,94$, and 127 days after transplanting the papayas plants. The ripen fruits of five plants from each replication that growing trend consistent were chosen to observation the fruit quality. Quality parameters such as the total acid and soluble-solid content were determined in accordance with the AOAC

116 (1989). The vitamin C content was assessed as described by Bessey and King (1933). Fifty grams of papaya flesh was well homogenized with $50 \mathrm{~mL}$ of $2 \%(\mathrm{w} / \mathrm{v})$ oxalic acid by using a kitchen blender, $20 \mathrm{~mL}$ of homogenate was diluted to $50 \mathrm{~mL}$ with $2 \%$ oxalic acid, and $10 \mathrm{~mL}$ of the solution was titrated with $2,6-$ dichlorophenolindophenol solution until it appeared pink in color. mixture was then centrifuged at $12,000 \times \mathrm{g}$ for $10 \mathrm{~min}$ at $4{ }^{\circ} \mathrm{C}$. After that, $0.1 \mathrm{ml}$ of ethanol extract was mixed with $1 \mathrm{ml}$ of $2 \mathrm{~g} / \mathrm{L}$ anthrone in $706 \mathrm{~g} / \mathrm{L} \mathrm{H}_{2} \mathrm{SO}_{4}$. The mixture was incubated at $100{ }^{\circ} \mathrm{C}$ for 15 minutes and cooled in a water bath, and the total sugar content was determined at $625 \mathrm{~nm}$. The protein content was measured according to a method described by Bradford (1976) with bovine serum protein as the standard, and the results were expressed in $\mathrm{mg} \mathrm{g}^{-1}$. Electrical conductivity was closely related with fruit storing time, and it was 
128

129

130

131

132

133

134

135

136

137

138

139

140

141

142

143

144

145

146

147

Japanese) with a $2 \mathrm{~mm}$ diameter stainless steel probe. The fruits were tested equatorially at their maximum diameter with a cross-head speed of $50 \mathrm{~cm} \mathrm{~min}^{-1}$. The force was expressed in Newtons $(\mathrm{N})$. The fruit numbers were counted at harvest. The individual fruit weights and total yields were measured from the fresh weights of the fruits.

\subsection{Statistical Analysis}

Experimental data were evaluated by analysis of variance (ANOVA), and significant differences between the means of three replicates $(p \leq 0.05)$ were determined by Duncan's multiple range tests with SPSS 13.0 for Windows. All figures were created in Origin version 8.

\section{Results}

\subsection{Plant growth}

Different fertilizer applications significantly increased the plant height and stem diameter growth parameters, and these positive effects were strengthened over time (Fig. 2). For the plant height, a significant difference was found only between the $\mathrm{E}$ and the $\mathrm{C}$ treatments on June 10 (55 days after planting), and on July 3 (76 days after planting), the plant heights of the $\mathrm{F}$ and $\mathrm{E}$ treatments were significant higher than that of the $\mathrm{C}$ treatment from July 3 ( $p \leq 0.05$ ) (Fig. 2b). On August, the plant heights of the E, F, and $\mathrm{O}$ treatments were $195.70,188.70$, and $172.60 \mathrm{~cm}$, respectively, which were $24.70 \%, 20.23 \%$, and $9.98 \%$ higher than the C treatments, respectively (Fig. 2b). The stem diameters showed similar increasing trends under different fertilizer applications (Fig. 2a). On Aug 24 (127 days after planting), the five treatments were also ordered E > $\mathrm{F}>\mathrm{O}>\mathrm{C}$, and there was a significant difference between all treatments $(p \leq 0.05)$. 


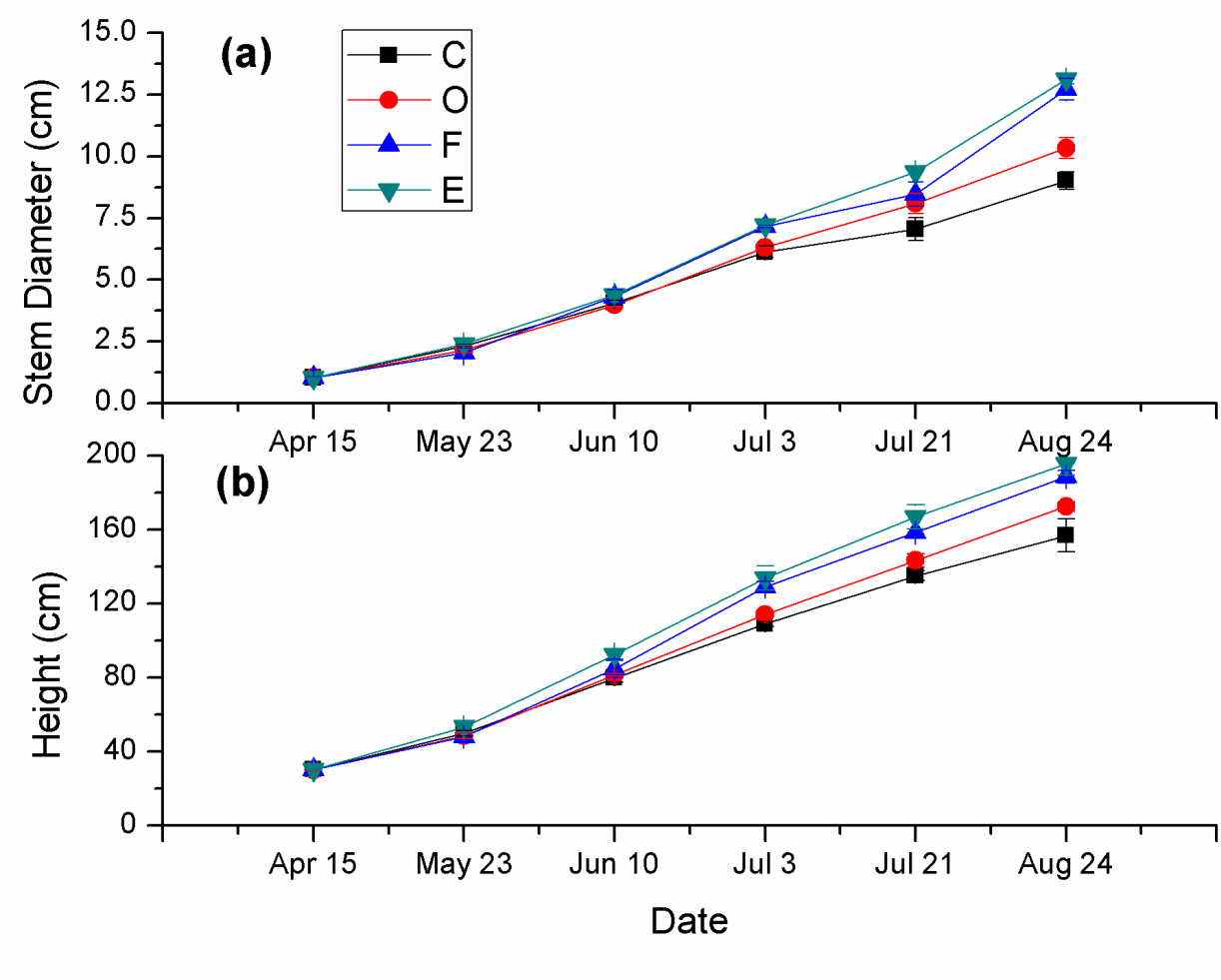

Figure 2: Plant heights and stem diameters under different fertilizer applications (mean \pm standard error, $\mathrm{n}=3$ ). $\mathrm{C}$ : control; O: compost, F: chemical fertilizer, and E: in situ earthworm breeding.

\subsection{Fruit quality}

There were significant differences of different fertilizer applications on fruit quality parameters such as the soluble-solid, sugar, vitamin $\mathrm{C}$, and protein content $(p \leq 0.05)$. The soluble-solid content in each of the four treatments was ordered $\mathrm{E}>\mathrm{F}>\mathrm{O}>\mathrm{C}$, and this parameter was markedly improved in the $\mathrm{E}$ treatment $(p \leq 0.05)$ (Fig. 3a). The soluble-solid content in the E treatment was $12.96 \%, 18.22 \%$, and $28.22 \%$ higher than the content of the $\mathrm{F}, \mathrm{O}$, and $\mathrm{C}$ treatments, respectively $(p \leq 0.05)$. The sugar content in the $\mathrm{E}(8.18 \%)$ treatment was also clearly increased, at 5.68\%, 31.09\% and 19.21\% higher than the sugar in the F, O, and C treatments, respectively (Fig. 3b). The vitamin $\mathrm{C}$ content in the $\mathrm{E}$ treatment was $132.95 \mathrm{mg} \mathrm{kg}^{-1}$, which was slightly higher than that of the $\mathrm{C}$ treatment $(p \leq 0.05)$ (Fig. 3c). The protein content in the $\mathrm{E}\left(2.45 \mathrm{~g} \mathrm{~kg}^{-1}\right)$ was also increased; it 
161

162

164

165

166

167

168

169 was $11.36 \%$ and $21.89 \%$ higher than the content of the $\mathrm{F}$ and $\mathrm{C}$ treatments (significantly different with $p \leq$ 0.05) (Fig. 3d).

The total acid, electrical conductivity and firmness were also affected by the different treatments. The total acid was dramatically decreased in the E treatment ( $p \leq 0.05$ ) (Fig. $4 \mathrm{a})$ and was reduced by $44.28 \%, 46.86 \%$ and $65.31 \%$ compared with that of the $\mathrm{C}, \mathrm{O}$ and $\mathrm{F}$ treatments, respectively. The electrical conductivity in the $\mathrm{O}$ and $\mathrm{E}$ treatments was obviously lower than that of the C $(p \leq 0.05)$; they dropped by $31.88 \%$ and $28.26 \%$ relative to the $\mathrm{C}$ (Fig. 4b). The fruit firmness was significantly enhanced in the $\mathrm{O}$, but it decreased in the $\mathrm{F}$ treatment $(p \leq 0.05)$ (Fig. 4c).
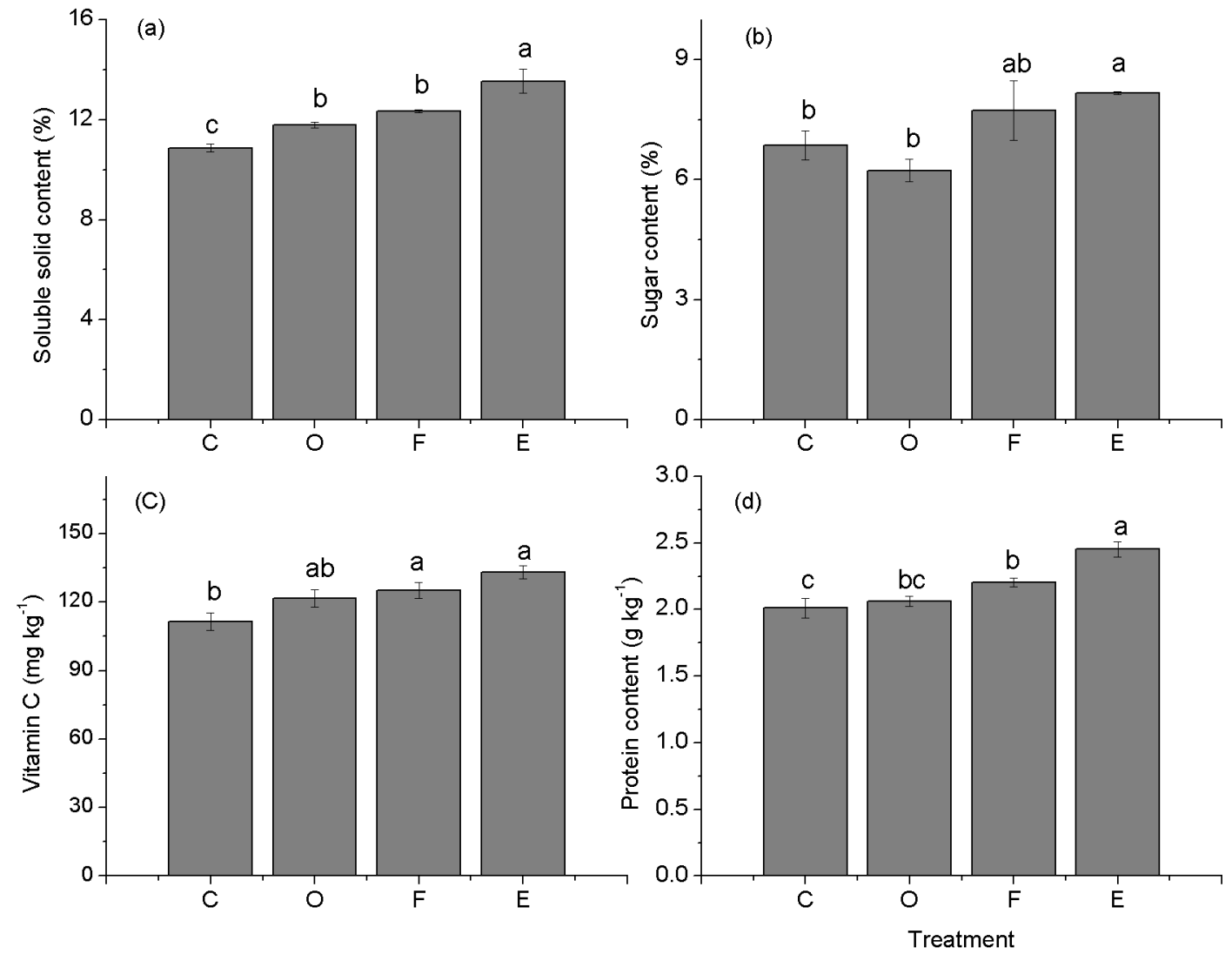

Figure 3: Soluble-solid, sugar, vitamin $\mathrm{C}$ and protein content of papaya fruit under different fertilizer applications (mean \pm 

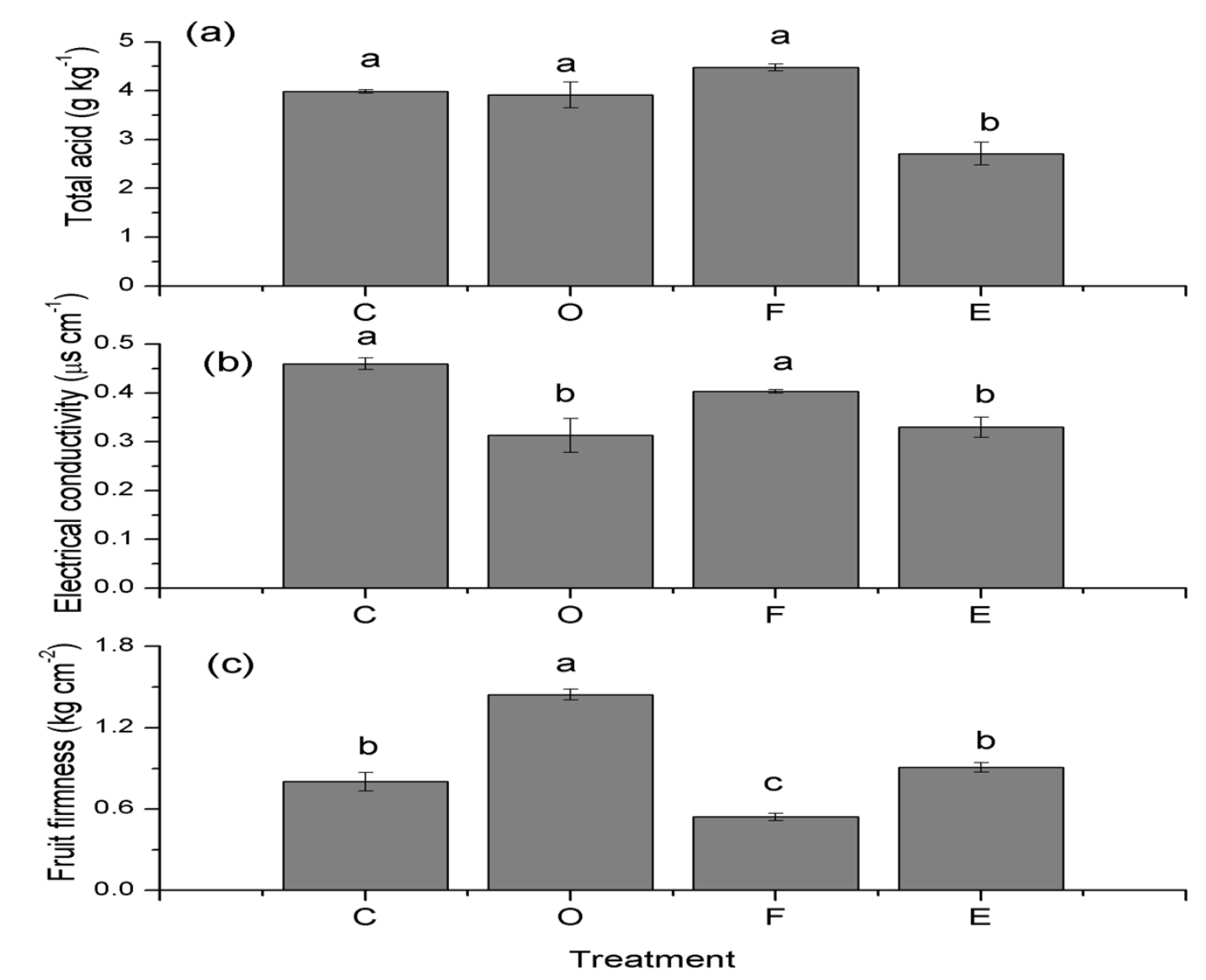

175

176

177

178

179

180

standard error, $\mathrm{n}=3$ ). Different letters indicate significant differences between treatments at $p \leq 0.05$. C: control; O: compost, F: chemical fertilizer, and E: in situ earthworm breeding.

Figure 4: Total acid, electrical conductivity and firmness of papaya fruit under different fertilizer applications (mean \pm standard error, $\mathrm{n}=3$ ). Different letters indicate significant differences between treatments at $p \leq 0.05$. C: control; O: compost, F: chemical fertilizer, and E: in situ earthworm breeding.

\subsection{Fruit yield}

The E treatment significantly enhanced the fresh weight per fruit, the fruit number, and the total yield (Table 3). The individual fruit weights for the four treatments were 373.48 (F), 359.17 (E), 299.47 (O), and $241.92 \mathrm{~g}$ (C). Compared with the $\mathrm{C}$ treatment, the $\mathrm{F}$ and $\mathrm{E}$ treatments were increased by $54.38 \%$ and $48.47 \%$, respectively. In addition, the fruit numbers and total yields were also significantly increased in the $\mathrm{F}$ and $\mathrm{E}$ treatments, and the $\mathrm{E}$ was higher than the $\mathrm{F}$. The quantities of fruits in the $\mathrm{F}$ and $\mathrm{E}$ treatments were $39.86 \%$ and 
186

189

190

$47.59 \%$ higher than that of the $\mathrm{C}$ treatment. The total yields of the $\mathrm{F}$ and $\mathrm{E}$ treatments were $116.60 \%$ and $120.62 \%$ higher than that of the $\mathrm{C}$ treatment, and the $\mathrm{E}$ yield was improved by $1.85 \%$ relative to the $\mathrm{F}$ treatment.

Table 3 Effects of different fertilizer applications on the papaya fruit number, weight, and total fruit yield of Hawaiian papaya.

\begin{tabular}{cccc} 
Treatments & $\begin{array}{c}\text { Individual papaya } \\
\text { weights (g) }\end{array}$ & No. of fruits/plant & $\begin{array}{c}\text { Total fruit yield }(\mathrm{kg} \\
\left.\mathrm{hm}^{-2}\right)\end{array}$ \\
C & $241.92 \mathrm{c}$ & $18.67 \mathrm{~b}$ & $4835.51 \mathrm{c}$ \\
O & $299.47 \mathrm{~b}$ & $21.44 \mathrm{~b}$ & $6927.87 \mathrm{~b}$ \\
F & $373.48 \mathrm{a}$ & $26.11 \mathrm{a}$ & $10477.19 \mathrm{a}$ \\
E & $359.17 \mathrm{a}$ & $27.56 \mathrm{a}$ & $10671.04 \mathrm{a}$ \\
\hline
\end{tabular}

The means within the same letter are not significantly different according to Duncan's multiple range test at $p \leq 0.05$. C: control; $\mathrm{O}$ : compost, F: chemical fertilizer, and E: in situ earthworm breeding.

193

\section{Discussion}

195

196

\subsection{Effects of different fertilizer applications on plant growth}

In this study, the $\mathrm{E}$ treatment significantly promoted papaya plant growth than the treatment of $\mathrm{C}$ and $\mathrm{O}$, and this treatment exhibited the highest plant heights and stem diameters of the four treatments over the whole growth period. Our result is consistent with other studies on earthworms in aboveground plant communities (Piearce et al., 1994; Wurst et al., 2005). The following mechanisms may be related to the results. First, the earthworm activities in the E treatment can improve the soil structure (such as the porosity) and increase the soil nutrients, and thus they provide a better root growth medium. Derouard et al. (1997) found that earthworms significantly affect soil aggregation and water infiltration. Lee (1985) also noted that earthworms alter the physical, chemical, and biological properties of soil, which can in turn modify the plant growth. In this study, we found that the nutrient content such as total $\mathrm{N}, \mathrm{P}$, and $\mathrm{K}$ in $\mathrm{E}$ treatment was higher than these in 
206 Second, the plant-growth hormones included in the fresh earthworm casts stimulated papaya growth.

207 Numerous studies showed that earthworm casts contain plant-growth-regulating materials such as humic acids

208 (Senesi et al., 1992; Masciandaro et al., 1997; Atiyeh et al., 2002) and plant-growth regulators such as auxins,

209 gibberellins, and cytokinins (Krishnamoorthy and Vajrabhiah, 1986; Grappelli et al., 1987; Tomati et al., 1990),

210 which contribute to increases in plant growth for many crops (Atiyeh et al., 2002). Thus, our study suggested

211 that in situ earthworm breeding in orchards can result in better plant growth.

2124.2 Effects of different fertilizer applications on the fruit quality

213 Soluble-solid, sugar, vitamin C, and protein content are very important parameters of fruit nutrition.

Increases in the content of these indices can indicate the enhancement of fruit quality. During this field

experiment, the E treatment significantly improved the fruit quality because it increased the soluble-solid,

sugar, vitamin $\mathrm{C}$, and protein content. The primary reason may be the presence of earthworm casts, which are

also known as vermicompost, in the E treatment. Vermicompost could improve the fruit quality, and our

results are consistent with previous studies. For example, Premuzic et al. (1998) reported that the fruits of

tomatoes grown on organic vermicompost substrates contained significantly higher vitamin $\mathrm{C}$ than those

grown in hydroponic media. Gutiérrez-Miceli et al. (2007) suggested that the addition of sheep manure to

vermicompost decreased the titratable acidity and increased the soluble and insoluble solids in tomato fruits,

compared with those harvested from plants cultivated in unamended soil. The beneficial effects of

vermicompost utilization for improving the fruit quality in other horticulture settings have also been reported

(Tomati et al., 1987; Hidalgo, 1999; Saciragic and Dzelilovic, 1986).

Moreover, the total acid, electrical conductivity, and fruit firmness were another three important indicators 
conductivity indicates a longer period of fruit storage, and the higher fruit firmness represents easier storage. In this study, the total acid and electrical conductivity decreased, but the fruit firmness was increased in the E treatment. Therefore, the E treatment that was incorporated into soil could effectively improve the fruit quality.

\subsection{Effects of different fertilizer applications on the fruit yield}

Our results suggested that the F and E treatments significantly improved the papaya yield. Several field studies have also found significant increases in fruit yields under earthworm inoculation and vermicompost application (Goswami et al., 2001; Gutiérrez-Miceli et al., 2007; Fragoso et al. 1997). Goswami et al. (2001) observed that vermicompost addition rates of $0,20,30$, and $40 \mathrm{t} \mathrm{ha}^{-1}$ produced tomato yields of $114,138,163$, and $192 \mathrm{t} \mathrm{ha}^{-1}$ in comparison with the inorganically fertilized tomatoes that received $56 \mathrm{tha}^{-1}$. Pashanasi et al. (1996) found that plant production was significantly increased by $36 \%$ following earthworm inoculation into a traditional low-input rotation. The role of earthworms in enhancing plant production depends on the synlocalization and the synchronization of their activities with the period and sphere of active root growth and nutrient demand. Most earthworm species release significant amounts of assimilable nutrients that can be supplied to the plants that grow in their casts (Syers et al., 1979; Lavelle et al., 1992). Earthworm activities promote the intense mineralization of soil, releasing considerable quantities of mineral $\mathrm{N}, \mathrm{P}$, and $\mathrm{K}$. This process may stimulate the plant growth and improve the fruit crop yield correspondingly. As the organic material is processed by the digestive systems of earthworms, vermicomposting differs from conventional composting. The higher $\mathrm{N}, \mathrm{C}, \mathrm{P}, \mathrm{K}, \mathrm{Ca}$, and $\mathrm{Mg}$ availability in vermicompost implies that it has a function as a slow release source of plant nutrients (Chaoui et al. 2003).

However, can the $\mathrm{E}$ treatment perform better than the $\mathrm{F}$ treatment in improving the total yield? In a previous study, $7.5 \mathrm{t} \mathrm{ha}^{-1}$ vermicompost was added to a treatment that increased the marketable fruit yield up to $58.6 \%$ 
248

relative to that of the inorganic fertilizer treatment (Singh et al., 2008). By contrast, the earthworms in the $\mathrm{E}$ treatment in our study were added only once, and the density of earthworms was only $8 \mathrm{~g} \mathrm{~m}^{-2}$. Therefore, we extrapolated that if the density of earthworms was increased in a proper range,, and it reached an appropriate standard, the effect of the E treatment in terms of improving the fruit yield would be much higher than that of the F treatment. Meanwhile, the price of buying the earthworms are low, it decreased the cost of agriculture. For example, in our study, the cost of F and E treatment was 22.19 and 15.29 USD ha $^{-1}$. The cost of E was lower than this in the F treatment. Though, the preparation of earthworm bed in E treatment was complicated. It can be seen one of the limitations of earthworm breeding. And also we could not determine if the E treatment would be suit for any type of papaya fields. This issue need be to studied further.

\section{Conclusion}

This study evaluated the effects of C, O, F, and E treatments on the plant growth, fruit quality, and yield of papayas. Of the four treatments, the E treatment provided the bestmedia for plant growth. The present study revealed that the E treatment was quite useful in field-grown papaya for conferring higher fruit quality and total yield. Generally, the incorporation of the E treatment with soil could significantly improve the growth, fruit quality, and yield of papaya in comparison with the $\mathrm{C}$ andO treatments. The $\mathrm{E}$ treatment could be used as an effective substitute for chemical fertilizer. Furthermore, the E treatment could be a potential organic fertilizer application because it not only improved the fruit's quality and yield but also reduced the amount of organic waste in agriculture as a result of the earthworm activities.

\section{References}

AOAC, 1989. Official methods of analysis, 14th ed. Association of Official Agricultural Chemist, Washington, DC, pp. $241-254$. Atiyeh, R.M., Lee, S.S., Edwards, C.A., Arancon, N.Q., Metzger, J., 2002. The influence of humic acid derived from earthworm- 
processed organic waste on plant growth. Bioresource Technology 84, 7-14.

Bernard, L., Chapuis-Lardy, L., Razafimbelo, T., Razafindrakoto, M., Pablo, A.L., Legname, E., Poulain, J., Brüls, T., O’Donohue, M., Brauman, A., 2011. Endogeic earthworms shape bacterial functional communities and affect organic matter mineralization in a tropical soil. ISME J. 6, 213-222.

Bessey, O.A., King, C.G., 1933. The distribution of vitamin C in plant and animal tissues, and its determination. J. Biol.Chem. 103, 687-698.

Bottinelli, N., Henry-des-Tureaux, T., Hallaire, V., Benard, Y., Mathieu, J., Duc Tran, T., Jouquet, P., 2010. How earthworms accelerate soil porosity under watering events. Geoderma 156, 43-47.

Bradford, M.M., 1976. A rapid and sensitive method for the quantisation of microgram quantities of protein utilizing the principle of protein-dye binding. Anal. Biochem. 72, 248-254.

Cantanazaro, C.J., Williams, K.A., Sauve, R.J., 1998. Slow release versus water soluble fertilization affects nutrient leaching and growth of potted chrysanthemum. Journal of Plant Nutrition 21, 1025-1036.

Caravaca, F., Hernandez, T., Garcia, C., Roldan, A., 2002. Improvement of rhizosphere aggregate stability of afforested semiarid plant species subjected to mycorrhizal inoculation and compost addition. Geoderma 108, 133-144.

Chaoui, H.I., Zibilske, L.M., Ohno,T., 2003. Effects of earthworm casts and compost on soil microbial activity and plant nutrient availability. Soil Biology \& Biochemistry 35, 295-302.

Derouard, L., Tondoh, J., Vilcosqui, L., Lavelle, P., 1997. Effects of earthworm introduction on soil processes and plant growth. Soil Biology \& Biochemistry 29(3-4), 541-545.

Doan, T.T., Ngo, P.T., Rumpel, C., Nguyen, B.V., Jouquet, P., 2013. Interactions between compost, vermicompost and earthworms influence plant growth and yield: A one-year greenhouse experiment. Scientia Horticulturae 160,148-154.

Fragoso, C., Brown, G.G., Patrón, J.C., Blanchart, E., Lavelle, P., Pashanasi, B., Senapati, B., Kumar, T.,1997. Agricultural intensification, soil biodiversity and agroecosystem function in the tropics: the role of earthworms. Applied Soil Ecology 6, 17-35.

Goswami, B., Kalita, M.C., Talukdar, S., 2001. Bioconversion of municipal solid waste through vermicomposting. Asian Journal of Microbiology, Biotechnology and Environmental Sciences 3, 205-207.

Grappelli, D.H., Gallli, E., Tomati, U., 1987. Earthworm casting effect on Agaricus bisporus fructification. Agrochimica 21, 457462.

Gutiérrez-Miceli, F.A., Santiago-Borraz, J.,Molina, J.A.M., Nafate, C.C., Abud-Archila, M., Llaven, M.A.O., Rincon-Rosales, R., Dendooven, L., 2007. Vermicompost as a soil supplement to improve growth, yield and fruit quality of tomato (Lycopersicum esculentum). Bioresource Technology 98, 2781-2786

Hidalgo, P., 1999. Earthworm castings increase germination rate and seedling development of cucumber. Mississippi Agricultural and Forestry Experiment Station, Research Report. 22 no. 6.

Jongmans, A.G., Pulleman, M.M., Marinissen, J.C.Y., 2001. Soil structure and earthworm activity in a marine silt loam under pasture versus arable land. Biol. Fertil. Soils 33, 279-285.

Jouquet, P., Dauber, J., Lagerl, J., Lavelle, P., Lepage, M., 2006. Soil invertebrates as ecosystem engineers: intended and accidental effects on soil and feedback loops. Appl. Soil Ecol. 32, 153-164.

Jouquet, P., Bernard-Reversat, F., Botticelli, N., Orange, D., Rouland-Lefèvre, C., TranDuc, T., Podwojewski, P., 2007. Influence of changes in land use and earthworm activities on carbon and nitrogen dynamics in a steepland ecosystem in Northern Vietnam. Biol. Fertil. Soils 44, 69-77.

Krishnamoorthy, R.V., Vajrabhiah, S.N., 1986. Biological activity of earthworm casts: an assessment of plant growth promoter levels in casts. Proceedings of the Indian Academy of Sciences (Animal Science) 95, 341-351. 
313

314

315

316

317

318

319

320

321

322

323

324

325

326

327

328

329

330

331

332

333

334

335

336

337

338

339

340

341

342

343

344

345

346

347

348

349

Lavelle, P., Melendez, C.1., Pashanasi, B., Schaefer, R., 1992. Nitrogen mineralization and reorganization in casts of the geophagous tropical earthworm Pontoscolex corethurus (Glossoscolecidae). Biology and Fertility of Soils 14, 49-53.

Lee, K.E., 1985. Earthworms: their Ecology and Relationships with Soils and Land Use. Academic Press, Sydney.

Masciandaro, G., Ceccanti, B., Gracia, C., 1997. Soil agro-ecological management: fetigation and vermicompost treatments. Bioresource Technology 59, 199-206.

Ndegwa, P.M., Thompson, S.A., 2001. Integrating composting and vermicomposting in the treatment and bioconversion of biosolids. Bioresource Technology 76, 107-112.

Ngo, P.T., Rumpel, C., Dignac, M.F., Billou, D., Toan, T.D., Jouquet, P., 2011. Transformation of buffalo manure by composting or vermicomposting to rehabilitate degraded tropical soils. Ecological Engineering 37, 269-276.

Ngo, P.T., Rumpel, C., Doan, T.T., Jouquet, P., 2012. The effect of earthworms on carbon storage and soil organic matter composition in tropical soil amended with compost and vermicompost. Soil Biology \& Biochemistry 50, 214-220

Pashanasi, B., Lavelle, P., Alegre, J., Charpentier, F., 1996. Effect of the Endogeic earthworm Pontoscolex corethrurus on soil chemical characteristics and plant growth in a low-input tropical agroecosystem. Soil Biology \& Biochemistry 28(6), 801-810.

Piearce, T.G., Roggero, N., Tipping, R., 1994. Earthworms and seeds. J. Biol. Educ. 28, 195-202.

Premuzic, Z., Bargiela, M., Garcia, A., Rendina, A., Iorio, A., 1998. Calcium, iron, potassium, phosphorus, and vitamin C content of organic and hydroponic tomatoes. HortScience 33, 255-257.

Pulleman, M.M., Six, J., Uyl, A., Marinissen, J.C.Y., Jongmans, A.G., 2005. Earthworms and management affect organic matter incorporation and microaggregate formation in agricultural soils. Appl. Soil Ecol. 29, 1-5.

Saciragic, B., Dzelilovic, M., 1986. Effect of worm compost on soil fertility and yield of vegetable crops cabbage leeks and sorghum hybrid yield. Agrohemija 3, 343-351.

Senesi, N., Saiz-Jimenez, C., Miano, T.M., 1992. Spectroscopic characterization of metal-humic acid-like complexes of earthworm-composted organic wastes. The Science of the Total Environment (117/118), 111-120.

Singh, R., Sharma, R.R., Satyendra Kumar, S., Gupta, R.K., Patil, R.T., 2008. Vermicompost substitution influences growth, physiological disorders, fruit yield and quality of strawberry (Fragaria x ananassa Duch.). Bioresource Technology 99, 85078511.

Syers, J. K., Sharpley, A.N., Keeney, D.R., 1979. Cycling of nitrogen by surface-casting earthworms in a pasture ecosystem. Soil Biology \& Biochemistry 11, 181-185.

Tomati, U., Grapelli, A., Galli, E., 1985. Soil microrganisms and long-term fertility. In long-term effects of sewage sludge and farm slurries applications, ed. J. H. Williams, G. Guidi \& P.l'Hermite, pp. 14-22. Elsevier Applied Science, London, UK.

Tomati, U., Grapelli, A., Galli, E., 1987. The hormone-like effect of earthworm casts on plant growth. Biology and Fertility of Soils 5, 288-294.

Tomati, U., Galli, E., Grappelli, A., Dihena, G., 1990. Effect of earthworm casts on protein synthesis in radish (Raphanus sativum) and lettuce (Lactuca sativa) seedlings. Biology and Fertility of Soils 9, 288-289.

Vu, T.K.V., Tran, M.T., Dang, T.T.S., 2007. A survey of manure management on pig farms in Northern Vietnam. Livestock Science 112, 288-297.

Wurst, S., Langel, R., Scheu, S., 2005. Do endogeic earthworm change plant competition? Microcosm Study Plant Soil 271, 123130. 